\title{
WestVirginiaUniversity
}

THE RESEARCH REPOSITORY @ WVU

Graduate Theses, Dissertations, and Problem Reports

2018

\section{Gas county: a case study on how West Virginia's recent gas boom is transforming a county}

\author{
Egill Karlsson
}

Follow this and additional works at: https://researchrepository.wvu.edu/etd

\section{Recommended Citation}

Karlsson, Egill, "Gas county: a case study on how West Virginia's recent gas boom is transforming a county" (2018). Graduate Theses, Dissertations, and Problem Reports. 4002.

https://researchrepository.wvu.edu/etd/4002

This Problem/Project Report is protected by copyright and/or related rights. It has been brought to you by the The Research Repository @WVU with permission from the rights-holder(s). You are free to use this Problem/Project Report in any way that is permitted by the copyright and related rights legislation that applies to your use. For other uses you must obtain permission from the rights-holder(s) directly, unless additional rights are indicated by a Creative Commons license in the record and/ or on the work itself. This Problem/Project Report has been accepted for inclusion in WVU Graduate Theses, Dissertations, and Problem Reports collection by an authorized administrator of The Research Repository @ WVU. For more information, please contact researchrepository@mail.wvu.edu. 
"Gas County: A Case Study on How West Virginia's Recent Gas Boom is

Transforming a County"

by

Egill Karlsson

Professional project report submitted to the

Reed College of Media

at West Virginia University

in partial fulfillment of the requirements for the degree of

\author{
Master of Science \\ in Journalism
}

Mary Kay McFarland, M.A., Chair

Timothy Carr, Ph.D.

Elizabeth Oppe, Ph.D.

Lois Raimondo, M.A.

Reed College of Media

Morgantown, West Virginia

2018

Keywords:

Copyright 2018 Egill Karlsson 


\section{Table of Contents}

Proposal.....................................................................3

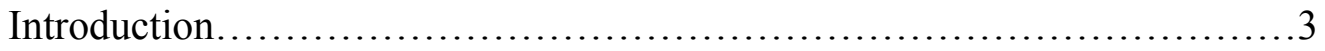

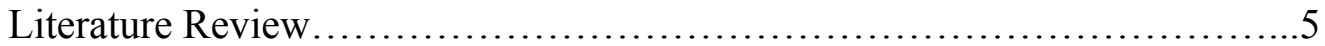

Changes from Original Literature Review................................22

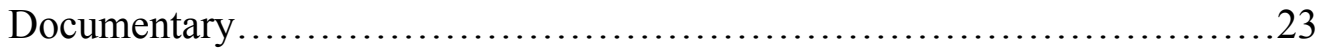

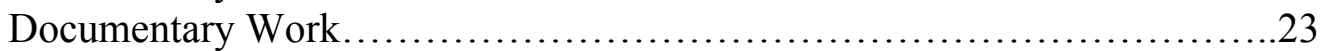

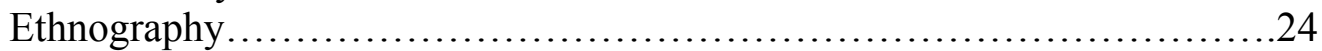

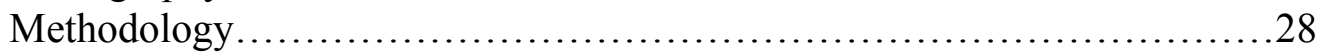

Changes to Methodology from Original Proposal.............................34

The Professional Project Summary ..................................35

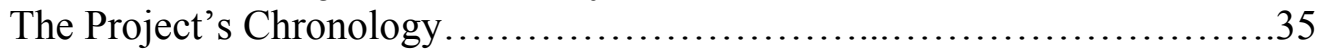

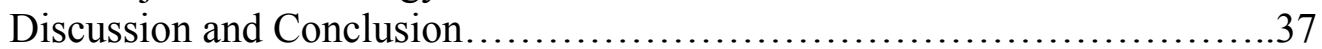

Limitations and Suggested Future Research................................37

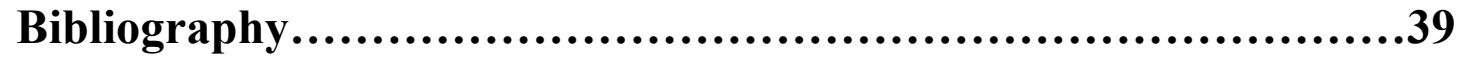




\section{Gas County the Project}

\section{Introduction}

The project Gas County: A Case Study on How West Virginia's Recent Gas Boom is Transforming a County is a multimedia website that revolves around the topic of horizontal hydraulic fracturing, sometimes called fracking, and focuses on a small county in West Virginia called Doddridge County. The project explores the impact the recent natural gas boom has had on the economy and environment of a small county through text, podcast episodes, photos, video, and an interactive timeline.

The key element of the website is a four-episode podcast that takes the listener on a journey to Doddridge County, where personal interviews with community stakeholders, both opponents and supporters of the industry, as well as academic researchers and specialists, give listeners a balanced picture of the community and the issues affecting the people who live and work there.

In addition, visitors to the website can explore a video about the increase in truck traffic in the county due to the increased industrial activity, and scroll through a timeline of events that show the relationship Doddridge County has had with natural gas since the $19^{\text {th }}$ Century. There's also a photo gallery to give you a visual feel of the county and the gas industry, in addition to textual information on hydraulic fracturing in the county and state as a whole.

The practice of hydraulic fracturing has been equally lauded and contested in the past decade, as it has had some visible economic benefits to the country as a whole, and for smaller areas like Doddridge County, where residents have seen prosperity through employment, increased business, and tax revenue. Some condemn the practice, claiming that the gas extractions contribute to contamination of water, air and poor physical health. This project attempts to use fact-driven, objective reporting to examine the tension between these varying ideas and opinions lived out in a small community and connect the audience to the concerns of the real people who make it their home.

Project website can be found on www.gascounty.com 


\section{Proposal:}

"Gas County: A Case Study on How West Virginia's Recent Gas Boom is Transforming a County"

Egill Karlsson

West Virginia University

Reed College of Media 


\section{Introduction}

The world's energy consumption is at an all time high, with the U.S. Energy Information Administration projecting a 48 percent increase in worldwide consumption in the next 24 years. Although renewable energy is the world's fastest growing energy source according to the report, fossil fuel will continue to supply more than three-fourths of world energy use for the next two decades (U.S. EPA, 2016d).

One of the fastest growing fossil fuel extraction methods today is called horizontal hydraulic fracturing (referred to here simply as "hydraulic fracturing"). In the $21^{\text {st }}$ Century, oil and gas companies have utilized this relatively new natural gas extraction technique, which involves horizontal drilling miles below the surface to extract immense amounts of natural gas for user consumption (Gandossi, 2013, p. 7). Thanks to hydraulic fracturing, the Environmental Protection Agency predicts that natural gas will surpass coal by 2030 as the world's second largest energy source (U.S. EPA, 2016d).

The economic impact of the emergence of hydraulic fracturing cannot be denied; creating jobs both directly and indirectly, it has lowered domestic gas prices for consumers and created tax revenue for states where drilling is taking place $(\mathrm{CBO}$, 2014, p. 2). Despite economic benefits, hydraulic fracturing remains a highly controversial practice. This is evidenced by numerous scientific reports and thousand of complaints reporting negative effects on the environment and people living in the vicinity of wells. Reports of polluting air emissions, water contaminations, earthquakes and other factors have created waves of protests around the nation demanding an end to the practice of hydraulic fracturing (CNN, 2011).

West Virginia is a state that has been deeply affected by hydraulic fracturing, with a large number of wells built and jobs emerging in the past decade (U.S. EIA, 2014). But just as with the gas extractions in other states, it is not without controversies. With 2,273 gas wells in the state being horizontal hydraulically fractured between 2008 and 2017, the West Virginia Department of Environmental Protection (2018) has seen almost 189 water-related complaints since 2010 (WV DEP, 2018), deadly work accidents, and a mass litigation nuisance lawsuit. On the flipside, it's generated enormous wealth through taxes, employment, and business. 
This project uses podcasts featuring interviews with various stakeholders to explore the tension between potential economic prosperity and the physical health of the residents in Doddridge County, West Virginia, where hydraulic fracturing is notoriously prevalent. The podcasts have been published on a website, gascounty.com, with text-based and interactive information to lend context and statistical information about the practice of hydraulic fracturing in general and in Doddridge County specifically.

For this project, I interviewed eleven individuals who have either extensive knowledge of hydraulic fracturing in Doddridge County and West Virginia, or are Doddridge County residents who's personal lives are affected by the gas extractions within their habitat; professors, inspectors, gas company employees, business owners, activists, and everyday residents caught in the middle of it all. The interviews will help the audiences gain a comprehensive understanding of the impact this nationwide practice can have on a small community, in this instance a county in West Virginia, whether it be from a research-, business-, social-, or community health perspective.

By giving voice to different opinions from the county and getting input from individuals professionally involved in the topic, a comprehensive approach can be reached. There is copious amount of information and stories on how hydraulic fracturing operations are shaping communities and states nationwide. But this project brings something new to the table; a qualitative, personal look into all facets of the community, seeing how viewpoints of different stakeholders are affected, as viewpoints of different stakeholders are explored; business owners, law enforcement representatives, educational institutes, in addition to the usual subjects; gas company employees, activists, and specialists. From an informational point of view, it shows the internal struggles of a county where, as opposed to many other regions where gas extractions are taking place, there's a lack of ways to make ends meet. For this reason, the cost-and-benefit ratio of economic prosperity versus potential environmental effects are constantly being weighted to varying degrees by the interview subjects. 


\section{Literature Review}

\section{The emergence of hydraulic fracturing}

Hydraulic fracturing, sometimes called fracking, is the process of stimulating a well by fracturing rocks with pressurized liquid. By injecting high-pressure fluids made up of water, chemicals and sand into gas-saturated shale or sandstone, drillers create cracks in the deep-rock formations. This allows petroleum, natural gas and brine to flow more freely. By forcing open existing fissures, the drill can extract oil or gas deep below the surface. (Gandossi, 2013, p. 7) Simply put, it's a method of accessing otherwise hard-to-reach natural resources by drilling horizontally a mile below the surface, tapping shale and other tight-rock formations ("What is Fracking?", 2016).

Although hydraulic fracturing has been in the limelight in the $21^{\text {st }}$ Century due to new technology, increased need for oil dependency in the United States and other factors (The Week, 2016), the practice of hydraulic fracturing is not new for the oil and gas industry. It dates back to 1947, with millions of wells having been pumped for the past 70 years, both domestically and internationally (American Oil \& Gas Historical Society, 2016). Even before that, fracturing as a method of stimulating shallow, hard rock as a way to extract oil dates back to 1860s in Pennsylvania, New York, West Virginia and Kentucky, using explosive fluids (American Oil \& Gas Historical Society, 2016). But it was not until the late 1960s that hydraulic fracturing emerged on a massive scale, when American geologists became more aware of the huge volumes of gas-saturated sandstones in the ground. Soon, hydraulic fracturing was being used in the United States, Canada, Germany, Netherlands and the United Kingdom, among other countries. (Mander, 1989, p. 179).

Horizontal oil and gas wells became popular in the late 1980s with operators in Texas, who found the horizontal wells more effective than vertical wells, due to the much larger contact areas with the target formation. With the new horizontal drilling technology, previously inaccessible locations of the shale could be reached, rendering the practice more lucrative as the quantity of shale gas available for capture increased dramatically.

In the $21^{\text {st }}$ Century, horizontal hydraulic fracturing has grown exponentially. The production of natural gas from shale in the United States increased more than 10fold in the past decade (Rosenberg, Phartiyal, Goldman \& Branscomb, 2014). One of the reasons for such developments is the discovery of huge formations of 
underground shale rock like the Marcellus shale that could have a profound effect on the energy market.

The Marcellus Shale, a marine sedimentary rock that stretches across Pennsylvania and West Virginia and spans into areas of Ohio and New York, is believed to hold the largest volume of recoverable natural gas resource in the United States, according to the U.S. Energy Information Administration (2012). Estimates about the possible gas yield of the shale vary greatly, but industry experts studying the 390-million-year-old shale, say it could single-handedly supply the entire U.S. gas consumption needs for anywhere from six to seventeen years (Beard, 2012).
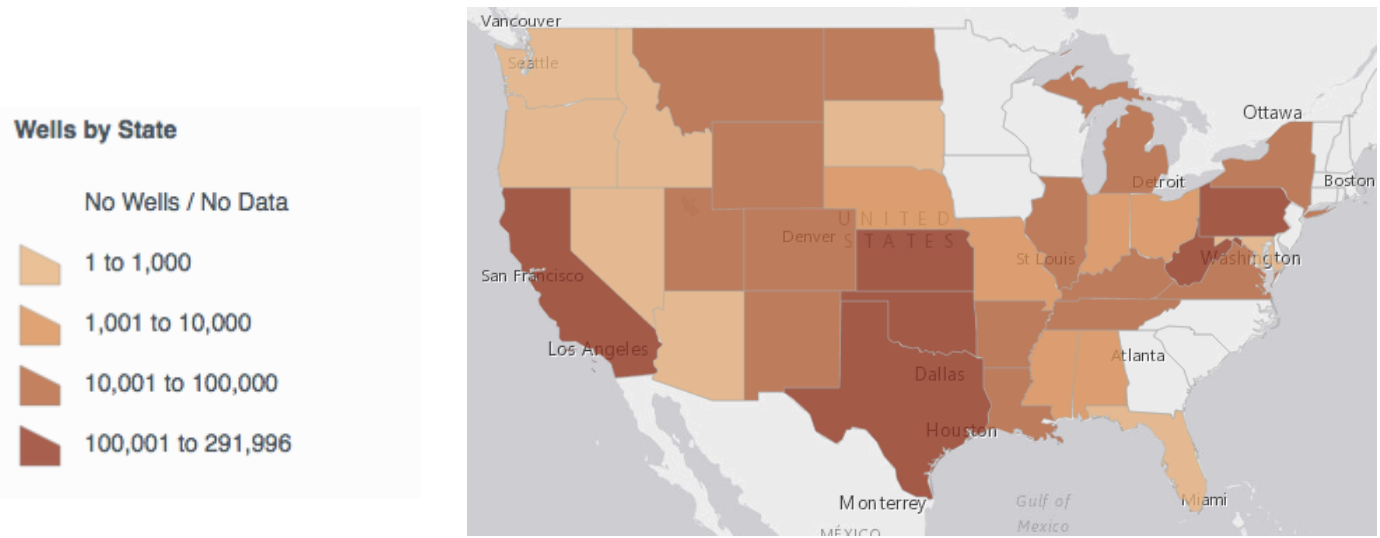

Density by state of active oil and gas wells in the United States in 2015 (Kelso, 2015).

By 2015, 1.67 million hydraulic fracturing jobs had been done in United States. Almost 90 percent of all onshore U.S. oil and gas wells today are hydraulically fractured. (Kelso, 2015). Since the horizontal drilling of the Marcellus shale began in 2003 it has generated economic benefits, with the surplus causing the natural gas prices to drop 47 percent since 2013 and gas bills to drop $\$ 13$ billion per year from 2007 to 2013 (Robbins, 2013, p. 1146). In addition, University of Michigan researchers estimate the economic welfare of consumers increased by about $\$ 74$ billion per year because of the lower cost of natural gas (Hausman \& Kellogg, 2015, p.3). 


\section{A controversial practice}

While gas companies and others maintain the stance that hydraulic fracturing is a safe and relatively environmentally friendly practice, others disagree strongly, referencing cases of adverse effects on health and the environment.

Although there is no lack of opposition to hydraulic fracturing from lawmakers, environmentalists and public health advocates, there is still a shortage of solid academic and fact-based research to prove hydraulic fracturing is a danger to the environment and public health. It's a relatively new practice in its current form so there is an absence of data, which is hard to obtain due to several factors, one being that U.S. gas operators are allowed to protect their proprietary formulas and are not required to disclose the chemical compounds used in the gas extraction process (Finkel \& Hayes, 2013, p 890).

When it comes to the health impact of hydraulic fracturing on residents living near wells, there is a vast array of scientifically backed claims concerning the health risks associated with practice.

\section{Pollution of water}

Not only do large hydraulic fracturing projects use up to 5 million gallons of water (Andrews et al., 2009, p. 33), which can affect river flow, power generation and water shortages (especially in dryer areas like Texas), they can also contaminate water supplies. This can occur at various stages of the extraction process and can be caused by the natural gas itself, toxic fluids used in the hydraulic fracturing process and other chemicals (Hausman \& Kellogg, 2015, p. 112).

According to a report by the Committee on Energy and Commerce (2011, p. 12) chemicals used in hydraulic fracturing include extremely toxic components like benzene, lead and methanol. In addition, the committee found 650 components that were regulated under the Safe Drinking Water Act, a federal law to protect public drinking water. Oil companies were given exemptions to certain sections of the Act, giving them more freedom to release chemicals and toxic substances into the environment.

According to the Environmental Protection Agency, approximately 9.4 million people in the United States live within a mile of where hydraulic fracturing is taking place (2015, p. 4). Needless to say, drinking water quality is important to these people and other residents nearby. 
There are a number of reports connecting horizontal wells to contaminated water in residential areas. In a two-year investigation by the Public Herald, an online investigative journalism publication from early 2016, Pennsylvania's Department of Environmental Protection received 2,309 water complaints coming from 17 of 40 counties where hydraulic fracturing took place. Of those complaints, 1,275 were about drinking water. In Bradford County, an area with a large amount of horizontal wells, the methane level rose aggressively between pre- and post-drilling tests, or from $8 \mathrm{mg}$ per liter to $40 \mathrm{mg}$. In Tioga County, complaints revealed contamination at levels far above the maximum limit for human consumption (Public Herald, 2015). These complaints are among 260 other cases that the Public Herald analyzed, uncovering similar results of contamination. A study by scientists at Stanford University concluded in 2016 that water sources at a hydraulic fracturing site in Wyoming were contaminated (DiGiulio \& Jackson, 2016), confirming the EPA's initial findings on the same site in 2011.

Supporters of hydraulic fracturing contradict findings like these. They maintain that oil and gas companies take measures to ensure prevention of contamination into local water supplies by isolating and sealing wells. As other factors unrelated to drilling can cause contamination of water, such as leaky septic systems or improper disposal of domestic refuse, disputes about who is to blame often need to be resolved by hydrogeological investigation; an expensive and timeconsuming process (Andrews et al., 2009, p. 26).

In 2015, the EPA published a report assessing the impact of hydraulic fracturing on drinking water in the United States. The agency found no evidence of systemic water contamination on drinking resources in the United States (U.S. EPA, 2015b). These findings have been criticized by environmentalists, who claim the EPA did report individual cases of water contamination, but since the agency couldn't find widespread systemic impacts on drinking water, the report has been used to claim the practice is safe (FactCheck, 2015). In fact, the EPA said the report makes no determination of safety, and the agency warns of uncertainties and data gaps identified in the report (U.S. EPA, 2015b, p. 41).

There is a critical mass of scientific evidence that links hydraulic fracturing to contamination of residents' water supplies. More studies are needed to confirm these findings unequivocally. 


\section{Air pollution}

One of the environmental concerns of horizontal hydraulic fracturing is the possibility of toxic emissions coming from the wells: these can include methane, diesel fumes and other toxic pollutants such as hydrogen sulfide and polycyclic aromatic hydrocarbons. Air pollution can occur during the extraction, transportation and distribution process due to the nature of gas.

Public health officials have linked carcinogens emitted by the gas extractions to an increase in cancer (Stanford, 2014, p. 68). The air pollutants have been reported to cause residents in proximity to the wells to experience respiratory problems, eye, nose, and throat irritation (Srebotnjak, \& Rotkin-Ellman, 2014). During a risk estimate conducted in Ohio, levels of air pollutants nearest to the wells were 30 percent higher than those in samples further away (Paulik et al, 2016). The Physicians for Social Responsibility (2014) even called for a ban on hydraulic fracturing, referencing reports of high-methane leaks and dangerous airborne levels of benzene near hydraulic fracturing operations. In another study conducted in Pennsylvania, researchers found that people with asthma who live near large horizontal gas wells are 1.5 to four times more likely to experience asthma attacks, compared to those who live further away, though authors are careful to note that their study doesn't show that hydraulic fracturing caused asthma or its symptoms (Rasmussen et al, 2016).

Hydraulic fracturing supporters point out that natural gas is a cleaner fossil fuel since it releases fewer nitrogen oxide and sulfur dioxide emissions when compared to oil (Omara et al, 2016). While that is true, it is debatable whether that outweighs the harm methane does to the environment, but it's unknown how much methane is release during the extraction process. As awareness increases and technology improves, initiatives by gas companies and others to reduce methane emissions have emerged (U.S. EPA, 2016c).

In a 2012 study from the University of Texas, Austin researchers found that most horizontal wells had equipment in place that cut their emissions by 99 percent, and methane emissions from these wells were significantly lower than previously thought (Allen et al, 2013, p. 5). The study was called into question due to the fact that Dr. Charles Groat, one of the head researchers behind the study, did not disclose the fact that he had was a board member of a drilling company, earning 1.5 million dollars over the course the last five years prior to the study. An independent review of the study also found numerous flaws and errors on how the study was conducted and 
released, although its focus was mostly on the execution of the research and lack of disclosure of conflicts of interests mentioned above. (Tribune Business News, 2012).

In a recent study from 2016, researchers at West Virginia University found emissions and toxic waste estimates at research wells near Morgantown, West Virginia well below federal guidelines for hazardous and radioactive waste. It should be noted that this is a tightly controlled well site by researchers, and the wells used a more environmentally friendly drilling mud called BioBase 365. All 12 cutting samples passed the EPA's standards for toxicity (West Virginia University, 2016).

There is certainly room for further studies on air emissions related to hydraulic fracturing operations, especially as global warming is causing climate patterns to change increasingly with every year, worldwide.

\section{Earthquakes}

The impact of drilling on earth stability is another concern. The rate of U.S. earthquakes in the past few years has increased dramatically (Ellsworth, 2013).

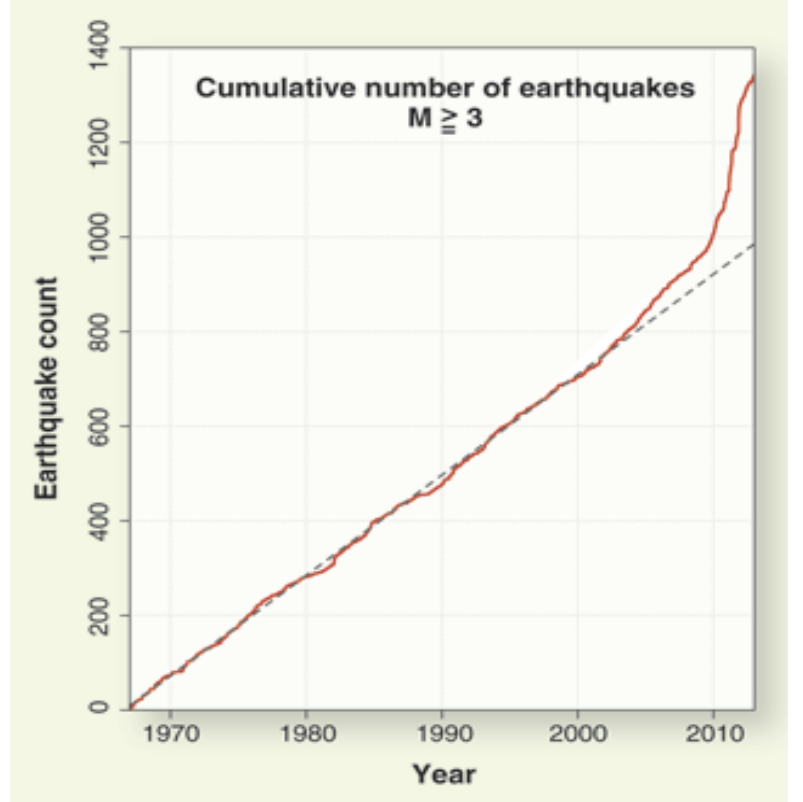

Number of earthquakes stronger than 3.0 Richter, between 1967-2012 (Ellsworth, 2013)

A 2016 study mapped out more than 900 earthquakes occurring near a drilling site in Alberta, Canada over the course of four months, including one earthquake with a magnitude of 4.8 , occurring in northern Alberta. In addition to discovering seismic activity far beyond "micro quakes", the geoscientists revealed that the earthquakes can even occur periodically; months after drilling operations have ceased (Bao \& Eaton, 
2016). In Oklahoma, environmental groups filed lawsuits against three energy companies because of the increased number of earthquakes in the region, one being the third strongest in the history of the state, a full 5.1 magnitude earthquake (Sierra Club, 2016). As of February 2017, the case was still pending (OK Energy Today, 2017).

The gas industry acknowledges that the hydraulic fracturing process causes thousands of small earthquakes. But this induced seismicity is done intentionally to create cracks in shale to extract gas, and they claim it is a relatively harmless part of the process. Some researchers say these routine earthquakes are too small to be felt by human beings and do not cause any structural damage. A study conducted in Texas in 2012 found that even though the number of earthquakes have been on the rise in the last decades and can be found near drilling sites, it's hard to unequivocally link earthquakes to hydraulic fracturing in the region, as massive population growth in the area and other factors need to be considered (Frohlich, 2012, p. 38).

But as researchers point out, this practice can induce larger earthquakes. Some of the largest earthquakes in the United States in 2011 and 2012 may have been triggered by hydraulic fracturing wells. A 2016 earthquake of 5.6 magnitude in Oklahoma, the largest one in the state's history, is believed to be directly connected to nearby horizontal wells. This has prompted legislative action, and the removal of 37 wells in the area has been ordered (CNN, 2016). In 2016, The United States Geological Survey announced that several states are at risk because of induced seismic activity (Petersen et al, 2016). There is substantial academic evidence that serious earthquakes are occurring as a result of hydraulic fracturing operations.

Beyond the health impacts, residents, who live near the horizontal wells, complain about the smell, sight and noise of the sites. Some of those living next to the drilling have reported not being able to sleep due to loud operational noises (TimesCall, 2014).

According to the Environment America Research \& Policy Center, environmental cleanup, heavy truck traffic that affects roads, and accidents and loss of property value for houses near wells are all examples of the economic damage the gas extracting operations have caused in different communities, from Texas to Pennsylvania. (Rumpler.\& Ridlington, 2013, p.17) 


\section{West Virginia: From Coal to Gas}

For one of the poorest states in the country, the emergence of oil companies drilling across the state has brought new life to the state's dwindling and fragile economy. The state's median income in 2015 was $\$ 42,019$, more than $\$ 13,000$ less than the national average (U.S. Census Bureau, 2016). The state was facing a $\$ 466$ million budget gap in 2017 (Washington Post, 2016), so it is no wonder that hydraulic fracturing has been welcomed by many West Virginians, because of its potential economic benefits through employment, taxation, land leases etc.

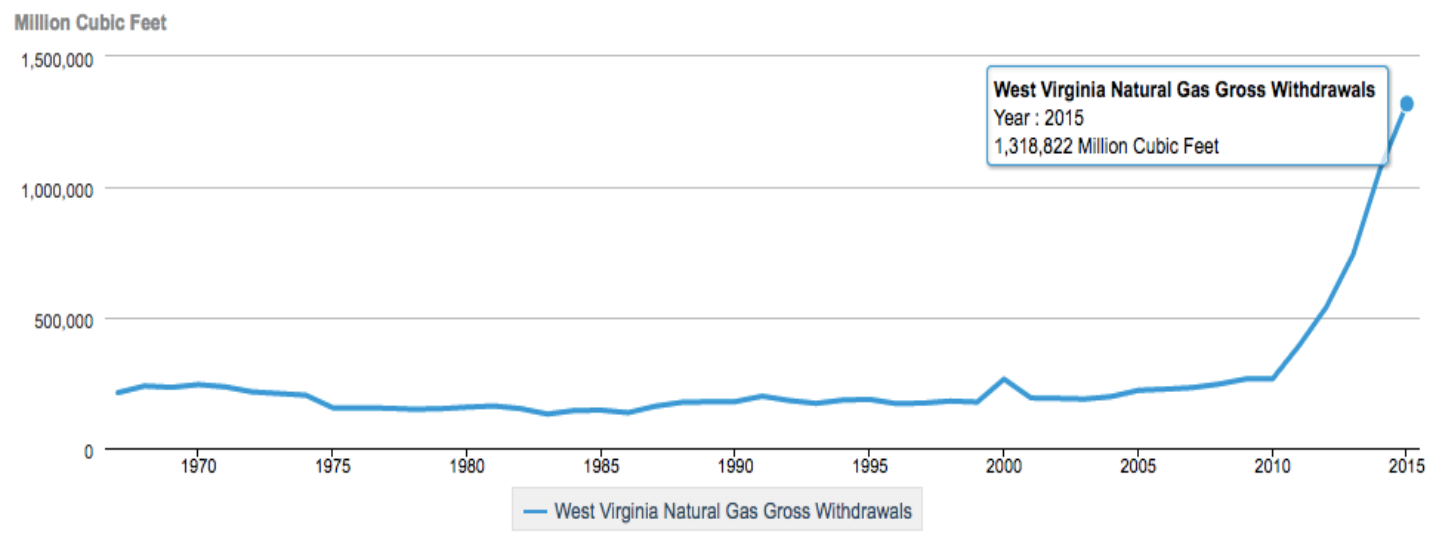

\section{The chart illustrates the hydraulic fracturing boom in the past decade in West Virginia (EIA, 2016a)}

West Virginia is no newcomer to fossil fuel. The state has strong historical- and economical ties with coal, being the second largest coal producer in the country, after Wyoming. West Virginia produced 11 percent of coal production in the country in 2014. As coal production, consumption and employment is declining - coal production in West Virginia fell 15 percent from 2014 to 2015, and coal industry employment decreased by 2,840 (16 percent) in the same year (U.S EIA, 2016b) - the state has seen hope in hydraulic fracturing. With the Marcellus shale under 29 of the state's 55 counties (Mineral Wise, 2016), West Virginia is the eighth largest producer of natural gas in the nation. In 2015, the gross withdrawal and market production of natural gas in the state was more than 1.3 million cubic feet (EIA, 2016b). 


\section{Why Is Coal Declining?}

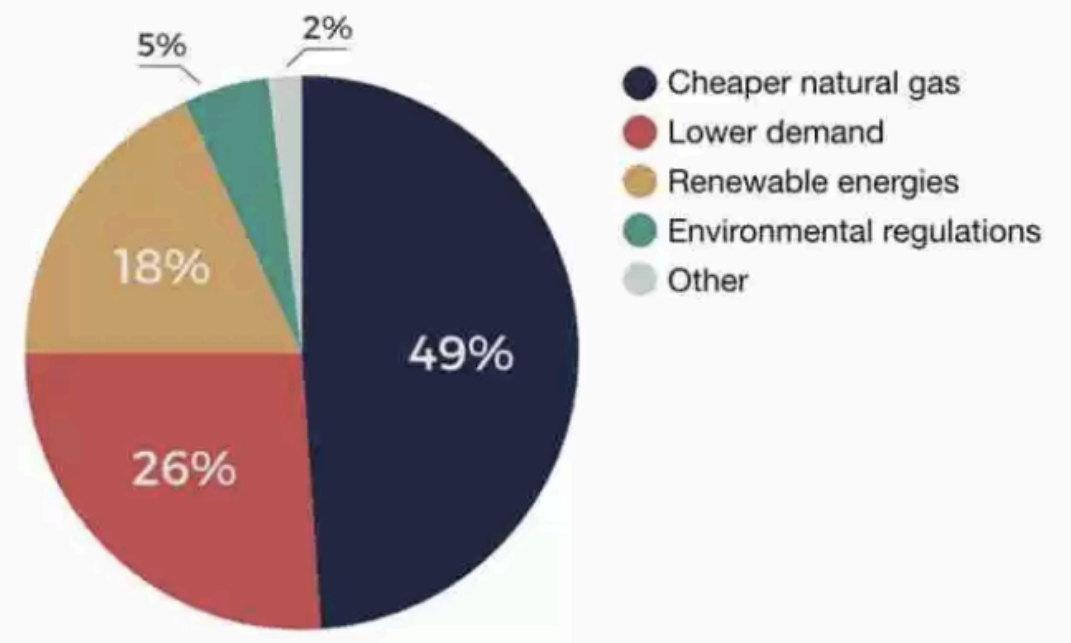

Source: Columbia Center on Global Energy Policy, Can Coal Make a Comeback? (2017)

The graphic above shows how the natural gas boom is a double-edged sword for West Virginia; The main reason for the decline of coal is not more stringent environmental regulations, a factor that is mostly blamed for coal's downfall, but really it's cheaper natural gas, according to a 2017 study Columbia University (2017).

Scientifically speaking, living and thriving near a gas well can have adverse effects on your health, according to several studies. A 2014 Colorado School of Public Health study found the risk of congenital heart defects and neural tube defects increase significantly for residents within 10 miles of hydraulic fracturing wells (McKenzie et al, 2014). In West Virginia, the wells may legally be $625 \mathrm{ft}$. from your property. A 2015 University of Pennsylvania study conducted in neighboring state Pennsylvania, reported the increase of inpatients correlated strongly with the increase in wells at each corresponding zip code from the years 2007-2011 (Jemielta et al., 2015). The West Virginia Department of Environmental Protection (2017) reports that from 2010, there have been 189 water-related complaints from residents within the state (although only one instance has a confirmed link to hydraulic fracturing (NIOSH, 2008)).

Some say that West Virginia has a history of prioritizing industrial activity over physical health concerns, referring it as the "sacrificial state". As evidence to support this notion, thirteen percent of coal miners in the state have been diagnosed with the so-called "black lungs disease", which develops from inhaling coal dust into 
the lungs (American Petroleum Institute, 2013). Couple that with the economic opportunities present within the natural gas industry, it's easy to see the appeal of the recent gas boom.

Those employed by the natural gas industry earn more than the state median, with the average "pumpers" earning around $\$ 35$ an hour; an average of $\$ 50,860$ a year in salary. In 2011, the oil and natural gas industry in West Virginia directly employed 35,925 people. According to the American Petroleum Institute (2013, p. e-3) the number rises to 80,400 people if employment throughout the supply chain of the natural gas industry is included. This amounted to 8.9 percent of employment in West Virginia in 2011. But some reports suggest that supporters of the industry have exaggerated the employment impact of the gas operations. Although the gas extractions have helped some counties in West Virginia to fight back from the worst economic recession, there was only a little over one percent growth in employment from 2005 to 2012 that can be traced to the emergence of hydraulic fracturing in the state (Mauro et al, 2013, p. 18).

Whatever the economic benefits, some believe they come at a great cost, primarily to the residents' health and the environment. In 2013, the state's legislators passed a new law allowing landfills in West Virginia to accept unlimited amounts of solid waste from hydraulic fracturing. Previously, they could only accept up to 30,000 tons a month. That same year, the state's landfills accepted 721,000 tons of waste.

An Environmental Science \& Technology study from January 2015 reported that two extremely hazardous chemicals linked with hydraulic fracturing, iodide and ammonium, were being released into West Virginia waterways (Harkness, Dwyer, Warner et al, 2016). A West Virginia Department of Environmental Protection study found that benzene concentrations at many sites in the state exceeded the acceptable risk level for causing health effects. Of the seven drilling sites examined, toxic hydrocarbons were found at every single one of them (Srebotnjak, \& Rotkin-Ellman, 2014).

Besides traditional health concerns normally related to the gas extractions, there are socio-political and physiological factors to be considered. One heated issue revolves around property ownership. The "surface rights" and "mineral rights" are two different things in West Virginia. Property owners might have rights to their land but not the area beneath (rich in natural gas), which may be owned by previous owners or government and possibly leased to private contractors. 
If residents do own the mineral rights and lease or sell those rights to a gas company, they may cause grievances from nearby residents (Sangaramoorthy et al, 2015, p. 32).

A 2015 study examined experiences and community perspectives in Doddridge County, West Virginia. In focus groups and interviews, many residents living near gas well sites expressed concerns with water quality and other threats to their health. But they also described how their environment had gone from peaceful and pristine to "an industrial wasteland" (Sangaramoorthy et al, 2015, p. 31). The social disruption was as much a problem to the community as the health issues. Some residents felt the gas boom had transformed social relationships into bitter fights over properties, and lack of rights cause many to feel exploited.

Further studies need to be conducted to examine the economic-, social-, health and environmental impact of hydraulic fracturing in West Virginia. For better or for worse, the natural gas industry might become a key element in shaping the future of the state in many ways.

\section{Doddridge County and the gas boom}

Named after Philip Doddridge, a lawyer and a congressman from Virginia who traveled widely throughout the current site of West Virginia, Doddridge County is situated in northern West Virginia, an hour drive south from the Pennsylvania border. With only 8,176 inhabitants on the county's 320 square miles of land, forests and mountainous farmland characterize the county. An exception is the city and county seat, West Union, incorporated in1881 (U.S. Census Bureau, 2017).

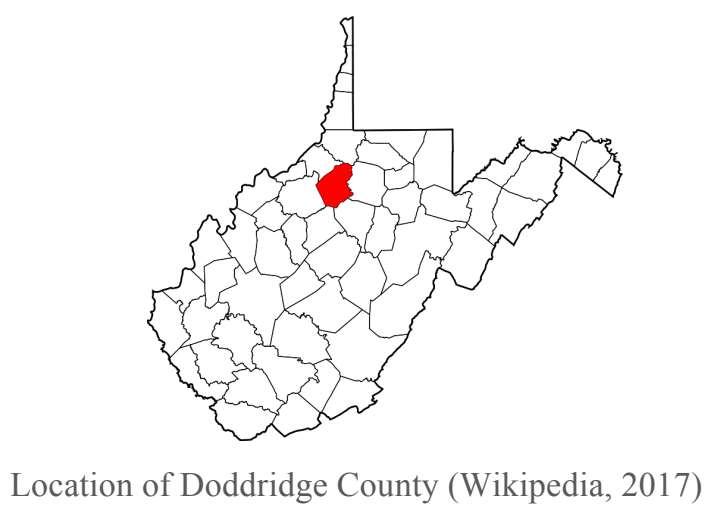

Similarly to the state as a whole, farming and coal mining have been an essential part of the county's economy for over a century. One can simply look at West Virginia's state seal, created by the Frenchman Joseph H. Diss DeBar. The seal pictures a miner 
with a pick, and a farmer with an axe. His model for the farmer was Henry Joseph Smith, a resident of Doddridge County; Debar lived in what is now West Union, a place he described as "picturesque" (WV Division of Culture and History, 2015).

The impact of the oil and gas industry in Doddridge County cannot be understated. Dating back to 1892, farmers started splitting their time between their regular farming and working for the oil industries and related fields, notably with companies called the Ideal Glass Factory and the Doddridge County Window Glass Company, who took advantage of the abundant natural gas. Production of oil and gas dwindled during the Great Depression, but a second boom surfaced in the 1960s. With the discovery of the Marcellus shale and advancement in horizontal hydraulic fracturing techniques, Doddridge County has been experiencing a third gas boom from 2008 (The West Virginia Encyclopedia, 2017).

\section{By the numbers}

Conventional wells have been a part of the county's modern history for a long time, and are still in use. In fact, there are 3,683 active conventional vertical wells on record in Doddridge County, according to the West Virginia Department of Environmental Protection (2017). A similar search for unconventional horizontal wells that are utilizing the Marcellus shale, yields smaller numbers, 854 horizontal wells have been permitted since 2008, around the time the hydraulic fracturing boom really started. At least 387 horizontal Marcellus shale wells are active in the county today (WV DEP, 2017).

Here's an example of why hydraulic fracturing is so popular among gas companies: In 2015, total Doddridge County gas production was 364 BCF (Billion Cubic Feet), while the Marcellus shale wells produced 331 BCF of that total, 91 percent. Again, 91 percent of gas production in the county came from 9.5 percent of the wells. Similarly with liquid production, 805 MBO (MBO: Thousand Barrels Oil) were produced in total in the year 2015 in Doddridge County, while 665 of those units were produced from the Marcellus shale, or 83 percent (WV DEP, 2015).

The emergence of hydraulic fracturing in Doddridge County for the past decade has been both contested and welcomed by residents. In a previously mentioned study of residents' perceptions and feelings about the ongoing drilling, some felt that the gas companies had turned the county into an industrial wasteland, 
while other touted the benefits of job opportunities and lower gas prices (Sangaramoorthy et al, 2015).

\section{Taxes}

Hydraulic fracturing has created substantial revenue for West Virginia and Doddridge County in the past decade. According to the State Treasurer, the state collects a severance tax from oil and gas companies, which is dedicated for the use and benefit of the counties and municipalities within WV. It's distributed annually, and 75 percent is distributed to the oil and gas producing counties. The remaining 25 percent is distributed to all counties and municipalities of the state, based on population. In 2016, Doddridge County received almost 1.7 million dollars in severance tax alone (WV State Treasurer, 2017).

Then there's the property tax. In 2015, property tax collection totaled over eight million dollars, the fifth largest amount of all counties in the state. In 2016, oil and gas property tax for the county was just over \$20 million, the second highest total in the state (The Intelligencer, 2016) Once again; constructions on pipelines, compressor stations and other gas-related facilities generate a good amount of property tax too.

\section{Employment}

Due to the West Virginia Bureau of Labor Statistics' privacy clause, it's hard to get a definite number of employees working in the hydraulic fracturing industry specifically in Doddridge County. There are also a good portion of jobs that are derived from the increase in natural gas extractions in the area, such as construction, transportation, and even the service industry. Antero Resources, EQT, MarkWest Energy and Dominion Energy all have a big presence in the county, and employ locals and out-of-state workers alike. Besides well completion and extraction, projects like Antero's \$250 million wastewater facility, built in 2016 (Marcellus Drilling News, 2016) and Markwest's in-construction \$200 million processing plant, both located in Doddridge County, have provided jobs both during construction and through its operations (The Exponent-Telegraph, 2017).

Out of all 50 counties in West Virginia, the rate of job creation was the highest in Doddridge County - 2.1 percent between 2005 and 2015. According to the US census bureau, $18 \%$ of the county's residents were employed in "construction and 
extraction" in 2015. In addition, transportation and other gas field-related jobs employed a good share of the inhabitants in the county. Although it's hard to decipher how many are employed precisely in hydraulic fracturing, given that 269 employees were working in "natural resources" in Doddridge County in 2017, while only 43 did in 2006 , there seems to be a correlation with the natural gas boom in the past decade (WorkForce WV, 2017). Again, many more are employed in other industries as a result of the gas industry.

\section{Traffic}

With increased industrial activity in the area comes more truck traffic. An unfortunate baggage of traffic is road deterioration and potential adverse effect on residents' health due to pollution. Various studies nationwide have found correlation between ultrafine particles derived from heavy traffic, and health effects such as low birth weight (Kipen, 2011), asthma (Lwebuga-Mukasa, 2005), heart diseases (Mills, 2007), and other illnesses.

It's not only people's health that suffers with increased traffic, but the states' wallet too. Road damage is prominent in areas where natural gas extraction activities take place, as can be seen in numerous states. In Texas, state-maintained roads have to be renovated for one billion dollars annually to accommodate drilling activity, and another billion dollars goes into fixing county-maintained roads. The revenues from the industry are substantial, but the cost of road repairs has outpaced it. In Arkansas, for example, the Highway and Transportation Department found that the damage caused to state highways by drilling traffic cost $\$ 217$ million to repair. The severance tax revenue received only covered one-seventh of that amount (WV Center on Budget \& Policy, 2014).

If we look at West Virginia and Doddridge County specifically, there has been an increase in truck traffic in the past decade due to increase gas extractions in the area. According to West Virginia's Department of Transportation's traffic data, 9\% of vehicles in 2005 inside Doddridge County were registered as trucks, but $26.2 \%$ in 2014 (WV DOT, 2017).

According to the Doddridge County's transportation division, the data is scarce on the amount of traffic going through the state. But it's not a stretch to look at neighboring Wetzel County; a county of similar geographical size and only slightly fewer hydraulic fracturing wells permitted since 2008; 357 vs. 409 (WV DEP, 2017). 
A report from 2014 shows that in 2005, 47 heavy truck permits were issued in the county. In 2012, a staggering 3,880 permits were issued for that same category. Understandably, repair and maintenance cost has also grown, increasing by 36 percent between 2007 and 2012. Vehicle related accidents increased from 197 to 310 between the years of 2007 and 2012. Between 2003 and 2008, only 11 heavy truck citations were given out, while the year 2009 alone yielded 75 citations (WV Center on Budget \& Policy, 2014).

Property- and severance taxes are partially used to fix and maintain the roads, and similar to what happens in Doddridge County, drilling companies often resurface and repair the roads they damage. The problem is, that they do so after they leave, and roads are often in bad condition while drilling is taking place.

Inside Doddridge County, it's easy to find residents that strongly oppose the practice of hydraulic fracturing, just like it's easy to find those who support it. Numerous residents protest the industry, both through rallies (WSAZ3, 2017) and on the Internet (Facebook, 2017).

\section{Health, hazards, and regulations}

The West Virginia Department of Environmental Protection's Office of Oil and Gas has received 189 water related complaints in the state since 2010, 54 of them coming from Doddridge County. The only confirmed case of unequivocal contamination of drinking water was due to a collision while drilling, as a Stella $1 \mathrm{~h}$ well collided with a functioning Callie $2 \mathrm{~h}$ well, resulting in contaminating four nearby private water wells (WV DEP, 2018). In general though, it's hard to find scientific evidence of water contamination in the state. If the number of complaints is compared to similar numbers from neighboring Pennsylvania, it's interesting to note that the PA DEP received 2,309 water-related complaints in roughly the same timespan. This difference in numbers can be explained by smaller size, and much tighter regulations in West Virginia.

At the end of the year 2017, The WV DEP Office of Oil \& Gas performed 4,166 total inspections statewide. Seven hundred of those covered the so-called fracking wells in question. Ninety-six compliance actions (WV DEP, 2018) were taken that same year regarding hydraulic fracturing operations. It's hard to get a wellspecific inspection count prior to mid-2016, as the department just changed the way inspections data is stored, but overall, the DEP does stay busy. Since 2011, the Office 
of Oil \& Gas performed over 12,000 inspections, 1119 of those resulting in some sort of compliance action issued (WV DEP, 2018).

\begin{tabular}{|l|l|l|l|l|}
\hline Year & Number & Total & Min & Max \\
\hline 2010 & 21 & $\$ 142,158$ & $\$ 400$ & $\$ 32,500$ \\
\hline 2011 & 21 & $\$ 450,930$ & $\$ 1,200$ & $\$ 80,000$ \\
\hline 2012 & 7 & $\$ 51,175$ & $\$ 1,350$ & $\$ 16,000$ \\
\hline 2013 & 29 & $\$ 790,135$ & $\$ 1,000$ & $\$ 275,000$ \\
\hline 2014 & 7 & $\$ 135,075$ & $\$ 7,600$ & $\$ 40,350$ \\
\hline 2015 & 7 & $\$ 240,550$ & $\$ 1,500$ & $\$ 203,175$ \\
\hline 2016 & 9 & $\$ 137,400$ & $\$ 2,000$ & $\$ 45,500$ \\
\hline 2017 & 6 & $\$ 88,125$ & $\$ 2,300$ & $\$ 12,000$
\end{tabular}

Infractions given out to gas companies in West Virginia, by year (WV DEP, 2018).

As shown above, the highest single fine for an infraction in 2013 was $\$ 275,000$. A single infraction in 2015 cost a company $\$ 203,000$. The fines range from $\$ 400$ to 275,000 , and although there were $\$ 790,000$ worth of fines given out in 2013, there were only six monetary fines issued in 2017 , totaling a little more than $\$ 88,000$.

Between 2009 and 2013, as the industry boomed, fifteen workers in the natural gas workers died on the job in West Virginia, according to federal data (Charleston Gazette-Mail, 2015). The most notable accident happened at hydraulic fracturing wells in Doddridge County in July 2013, when five men received severe burns and two of them died in a series of explosions at an Antero well site in the county. A spark triggered a flash explosion and a fire after a problem during the flow back process when drilling fluids are pumped into storage tanks. Although not resulting in water contamination, it had much graver consequences. (The Exponent Telegraph, 2013).

\section{Changes from original literature review}

Since the original proposal, some changes and additions were made. Data regarding adverse health effects of living near the wells, and the rise in number of inpatients in Pennsylvania were added. This was done to show factual correlation between number of gas wells and a rise in hospital visits. Unfortunately, similar data could not be found on West Virginia, so Pennsylvania was used as a comparison. 
The chapters Taxes, Employment, Traffic, and Health, hazards and regulations were added in its entirety. In previous literature review, the word fracking was used primarily, but was changed to hydraulic fracturing, due to fracking being possibly derogatory towards the natural gas industry.

While the scientific community is working towards a definite conclusion about the safety and viability of horizontal hydraulic fracturing, the documentary and ethnographic approach brings something new to the table; a way for people to connect with the topic through personal stories. By documenting people's stories and showcasing them side-by-side, the audience can compare different perspectives and philosophies on this controversial topic, while acknowledging the tension in the different core values at work.

\section{Documentary}

Documentaries come in various forms, using moving pictures, still photographs, audio recordings, or a mixture of different mediums to convey stories. But unlike fiction, the documentary style relies heavily on conveying an impression of realism and authenticity (Nichols, 2010, p. 8). Documentaries often revolve around debated concepts and issues. The documentarian can contribute a distinct perspective, and different filmmakers and photographers can come to a different conclusion about a topic, just as a judge or a jury member might come up with different opinions about the same issue (Nichols, 2010, p. 103). The power that documentary creators have cannot be underestimated as they have the means to paint a completely one-sided picture. Therefore, extensive data gathering and fact checking are vital to documentary work.

A skilled documentarian can capture the most revealing moments in a story, reproduce fine details and transcend barriers of language and nationality with his work._To set guidelines and learn from other people's documentary work on communities affected by the hydraulic fracturing operations, it is important to inspect what has previously been done through documentaries and other multimedia work in terms of hydraulic fracturing and similar issues. 


\section{Documentary work}

Gasland. Directed by Josh Fox, this Academy Award- nominated documentary from 2010 revolves around communities in the United States affected by hydraulic fracturing. In the film, Fox speaks to representatives of gas companies, lawyers and lawmakers, scientists and most importantly, residents who have been affected by gas extractions in their communities, often experiencing various chronic health problems related to water and air contamination (Fox, Adlesic \& Gandour, 2010). The release of the film spurred anti-hydraulic fracturing movements, heightened mass media coverage, increased social media chatter, and generally, reshaped public discourse (Vasi, Walker \& Johnson, 2015: p. 937).

Dear President Obama. A 2016 documentary narrated by actor Mark Ruffalo, Dear President Obama strongly condemns hydraulic fracturing, saying that in President's Obama's term, the practice had been left mostly unchallenged to expand into the huge business it is today. The film takes a look at horizontal gas wells around the country and their supposed contaminations, stories of people victimized by the practice, and what the filmmakers call "the false promise of the economic boom" (Bowermaster \& Ruffalo, 2016). The documentary also focuses on more clean energy solutions that don't rely on fossil fuel extraction. Original interviews, visual footage of the natural gas industry and people it affects, snippets from news segments of political leaders alongside Mark Ruffalo's narration makes Dear President Obama a compelling documentary.

Fracknation. As a counter argument to Gasland and other anti-hydraulic fracturing works and movements, Fracknation is a 2013 documentary by Irish journalist Phelim McAleer that addresses the concerns about hydraulic fracturing that, according to him, include a great deal of misinformation. As McAleer fact-checks and criticizes the way the hydraulic fracturing process and its consequences are portrayed in Gasland, he interviews individuals affected by hydraulic fracturing, who mostly support the practice. Some claim that the film is a pro-hydraulic fracturing documentary. McAleer denies that, saying he is only combatting the one-sided narrative by the media. According to him, journalists haven't been willing to factcheck environmentalists' claims and have relied on emotions and scare tactics to condemn the practice. To avoid being labeled as pro-industry propaganda, McAleer 
funded Fracknation completely through crowd funding, and turned down any support from the gas industry (McAleer, Segieda \& McElhinney, 2013).

"In the Air: Visualizing What We Breathe" - Though not specifically about hydraulic fracturing, "In the Air" was a series of photo essays by photographers Brian Cohen, Scott Goldsmith, Lynn Johnson and Annie O’Neill illustrating the environmental, social and economic effects of air quality in western Pennsylvania. A panel of photographers discussed their work at the West Virginia University Reed College of Media Innovation Center in August 2016. The project's purpose was to bring the pollution that is causing health issues among individuals to a new light; allowing people to visualize what they are actually breathing in. Each photographer had their own specific way of showing the effects and pollution and had their own story to tell (Cohen, Goldsmith, Johnson \& O’Neill, 2016).

In the exhibit, among the photos were vivid pictures of the environment and its cohabitation with power plants, railways and other sources of pollution. Another important part of the photo exhibit was portraits of people affected by the air quality.

The detailed captions and text describing residents' feelings and their respiratory- and other health problems, helped viewers understand the gravity of the situation and the human cost on a more personal level.

Coal: A love story. This interactive website is mainly composed of video segments revolving around communities and people affected by coal. This 'Powering a Nation" project by News 21, a reporting organization composed of journalism students across the country, also has graphics and text-based information set up on an easily accessible website. (News 21, 2011). The stories focus on people who work in the coal industry and believe that coal is an integral part of the community's life and economy, while also showing the fear of mining accidents that families experience and the real risk of black lung and other health realities. One part of the site is dedicated to a story of a young man in the suburbs of Chicago, fighting pollution and raising awareness about the dangers of a nearby coal factory. Another story is one of a coal miner's daughter who is proud of her father's profession and her heritage.

NPR: Planet Money Podcast: Episode 3: How Fracking Changed the

World. Episode 3 of NPR's Planet Money podcast is a audio episode about the discovery of hydraulic fracturing and how it's considered both boon and a curse depending on how you look at it. In this episode of a five-part series, the hosts of Planet Money discuss hydraulic fracturing and talk to an oil engineer about his views 
on the practice today, his feelings of regret and pride, and other personal issues.

Although this episode talks specifically about hydraulic fracturing, the premise of the show is the hosts buying 100 barrels of oil and following them out of the ground, through the refining process and all the way into someone's gas tank. (Planet Money, 2016) It is an interesting and easy-to-follow, first-hand account of oil industry business, through the medium of audio.

Gasland Website. An explorative website, directly connected to the movie Gasland, lets the user navigate through an interactive map of the United States, watching video segments with individual stories of people affected by hydraulic fracturing in their respective home regions. The site also has a "frequently asked questions" section where questions challenging the anti-hydraulic fracturing claims made in the movie and elsewhere are answered. It's a website that is text-driven, but includes videos and an interactive map in addition to links and encouragement to "take action" by signing petitions and contacting local officials (Fox, Adlesic \& Gandour, 2017).

The topic of hydraulic fracturing has been explored through various mediums in the past decade. Still, in terms of hydraulic fracturing, there is a lack of documentary work specific to the state of West Virginia. Documentaries like Gasland and Fracknation are not filmed in the state, but mostly focus on the neighboring state of Pennsylvania. Although both states are connected through the Marcellus shale, they have a vastly different political and economic landscape. While Pennsylvania can fall back on more diversified resources, a larger population and its more diverse industrial economy (Ryan, 2016), West Virginia is a state that has relied on fossil fuel throughout its history. It has been hit hard by the downturn of coal in the past decade. This project was an important step in getting to know how West Virginians envision the future of their state. The tension between economic prosperity and the community's environmental and physical health was of primary focus.

\section{Ethnography}

As the project revolved around people in rural West Virginia more specifically Doddridge County, ethnography (the systematic study of people and cultures) was an integral part of the project, whether it is for understanding the background of West Virginia's residents and their connection with both nature and fossil fuel, or to help 
the researcher's understanding of people's situation and environment, free from ethnocentrism. Academic studies and data collection, especially those utilizing quantitative methods, may not dwell deeply into people's complex emotions and personal stories. That is why ethnography is an important tool in creating a multilayered understanding of the issue at hand. Also, this project relies to some degree on the researcher's method of exploration; being able to gather and inquire about unexpected information in the interviewing process.

Ethnography uses field observations to learn about specific communities and cultures. As with other qualitative methods, it is more concerned with description and explanation than it is with measurement and quantification (Wimmer \& Dominick, 1991, p. 140). For certain research purposes, ethnography is not the best method due to the fact that samples of subjects used may not be the perfect representation of the group. In fact, it is often considered more ambiguous than in most other research approaches, and relies heavily on the researcher's perceptions, in addition to his preconceived notion. (Wimmer \& Dominick, 1991; p. 142). But despite lack of control and quantification, it is sometimes the only appropriate method. It doesn't rely on predetermined examinations with standardized questionnaires, but is more explorative in nature.

By employing intensive interviews, ethnography is really helpful in giving an unrestrained voice to the subject. This is paramount in this project, which seeks to study the values of community members in tension with each other. It's in the researcher's power to document and understand the communication of meaning (Altheide, 1996), and to realize the highly interactive nature of the method, and identify quickly the importance of what he documents.

Documentaries and ethnographies often intertwine. They both use careful background research to document and understand human experiences. For example, anthropologists Margaret Mead and Gregory Bateson documented complex rituals of tribes in New Guinea by using frame-by-frame film in the late 1930s (Henley, 2013), a tradition that has become common in anthropology as a method of documentation. Similarly, filmmaker Josh Fox, creator of the anti-hydraulic fracturing documentary Gasland (2010), travelled across the United States to observe communities affected by the practice. One might even say that ethnographies and documentaries are different sides of the same coin. That is why ethnography fits well into the framework of this project; it is as much ethnography as it is an audio documentary/podcast. 


\section{Methodology}

This project resulted in a website comprised of a series of podcasts and portraits of the interview subjects, a section with text-based information, a video piece about the resulting truck traffic in the county, a photo gallery of the area and industrial activity in question, and an interactive timeline with the history of Doddridge County and its ties to natural gas from its beginning. The website is accessible to all.

The series of four podcasts revolved around the experiences of people inside Doddridge County, exploring the tensions between potential economic prosperity due to gas extractions in the county versus the environmental and health effects it potentially has. The aim was to interview people with varying opinions, so the podcasts show the diversity in attitudes towards the industrial practice in a community. The sample of people had commonality in that they are community members living near gas well sites, who have been affected, positively or negatively, by the practice. In addition, the podcasts include interviews with academic individuals knowledgeable about hydraulic fracturing and people involved in the business side of the practice, to get an outside view and portray a holistic approach to the topic. All interviews were recorded with an audio recorder, and DSLR camera was used to take a portrait of each subject after the interview.

By documenting the community life and concerns of West Virginians living near gas well sites, the podcasts - using coherent narration, carefully crafted interviews, observation of the environment and artistic design to capture the audience's attention and create empathy for the subjects - can portray the issue in a way data and scientific studies can not.

People affected by hydraulic fracturing operations in rural West Virginia come from different backgrounds and have different stories to tell, even fundamentally different opinions about the practice and its impact on the state. The series of podcasts represent the wide spectrum of opinions related to the practice.

For this project, the aim was to interview a variety of subjects representing different demographics in order to thoroughly explore the themes discussed. The demographics interviewed were the following:

1. Two residents opposed to hydraulic fracturing. Both of them were in the senior category, and had a long history of living in Doddridge County. They 
had different backgrounds, and different family statuses. They both easily lived within a five-mile radius of hydraulic fracturing wells, an initial criterion for all my residential interviewees.

2. Three residents that fit in between the categories of opposition (activists) and support (gas company employees/industry supporters), meaning every day residents who have non-gas related occupations. The objective was to see how the gas extractions had affected them personally, and economically. They were of different occupations, background, gender and slightly different ages.

3. Two gas company employees, with completely different roles within the work chain; of different generations, with different backgrounds, views, and experiences.

4. Three specialists, studying hydraulic fracturing from a removed, but academic perspective. One was from a public health side, one from a research/engineering side, and the third a specialist in water research.

5. A DEP inspector, someone who is objective, but fully involved in a key element of the project; regulations and processes within West Virginia.

The interviewees were as follows:

1. Lyndia Ervolina - a senior citizen living in Doddridge County.

Retired, Lyndia and her husband Anthony moved to Doddridge County to spend their retirement in the beautiful mountain region, characterized by peace and tranquility, where hunting and fishing was easy and they could spend the rest of their days in a charming house next to a local creek, running through their large garden. According to them, this all changed when gas companies moved into the area and set up several gas wells, and according to the couple, polluted the local water sources in addition to releasing toxic fumes into the air as a result of their practices. Truck traffic has increased tremendously, resulting in noise pollution. They say hydraulic fracturing fluids spilled in nearby creeks and driveways, causing them, their grandchildren, trees and animals to suffer various health problems and deterioration. Their story is important to the project as it showcases what many community members are going through. Their narratives include the history of the area before hydraulic fracturing began, how it has changed and the challenges they 
face. It introduces the audience to people for whom gas extraction is a negative.

2. Mirijana Beram - a senior citizen resident of the West Union area of Doddridge County.

She used to work for the oil and gas industry, but now spends a good deal of time fighting them as an activist, attending meetings, workshops and other related activities revolving around the fight against hydraulic fracturing. Beram claims that there has been a huge increase in truck traffic in her area with damage to road infrastructure, and noise pollution from compressor stations (of which there are three within a few miles of her house). She says she has experienced a large amount of stress and depression as well as respiratory issues and loss of personal time waiting for roads to clear from truck traffic. The huge decline in the property value of her house is another side effect of the gas extractions near her home.

Her story also touches on the financial loss as a result of the nearby gas operations, with her property's value being dramatically lowered in the past decade. She has extended family in the area so she is able to give a first-hand account of the effects it has on younger individuals being raised in the environment.

3. Dr. Gregory Kuhns, - the principal of Doddridge County High School.

He gives the project great insight on how the gas boom has impacted the youngest generation in the county, what role it plays in the educational system, and what sort of perception the teenagers have on the gas extractions.

4. Sheriff Michael Headley - Sheriff of Doddridge County.

Headley has great insight and personal experience of how the gas boom has affected crime, truck traffic and disputes within the county. This is an important aspect of looking at all side effects of the hydraulic fracturing gas extractions in the county. Since he's a veteran sheriff, he's able to give a historical comparison of how things were before, and after the gas boom started.

5. Christina Trent - owner of Slick's Auto Detail Shop.

Trent is a business owner, who owns an auto detail shop in West Union. A lifelong Doddridge County resident, her story shows how the hydraulic fracturing boom has had beneficial economic effects on everyday 
businesses. As she admits to the traffic having adversely increased, it also shows how many residents have compromised, even though they support the practice.

6. Dr. Michael McCawley - Health Sciences Professor

Dr. McCalwy works in the Department of Occupational \& Environmental Health Sciences in the School of Public Health at West Virginia University. He's been working on issues related to Marcellus Shale drilling, and is very knowledgeable about the horizontal gas extraction process, the state of hydraulic fracturing in West Virginia and health effects of the practice. He is often in the field collecting water and air samples, and has collected scientific data related to pollution, all across the state.

Professor McCawley brings an important part of the story to the project; a detailed explanation on how hydraulic fracturing works and scientific explanation on of how hydraulic fracturing can potentially pollute its environment. His expertise on the subject, and his stories of people in West Virginia that he has encountered through his work, are invaluable and gives the project a broader scope.

7. Dr. Henry J. Harmon - Deputy chief of the Office of Oil \& Gas at West Virginia Department of Environmental Protection.

Dr. Harmon knows exactly what the regulations, processes and infractions are surrounding the hydraulic fracturing industry. He gives personal insight and both debunks and confirms widely held beliefs about the gas industry in West Virginia, and how the DEP operates.

8. Dr. Paul Ziemkiewicz - Director of West Virginia Water Research Institute

Highly knowledgeable about water contamination and natural gas drilling's effect on it, Dr. Ziemkewicz's input is important in terms of explaining the complexities of groundwater chemistry and how hydraulic fracturing effects its ecosystem.

9. Joshua Fershee - Center for Energy and Sustainable Development

Professor Fershee has vast experience in research in terms of economic, environmental and social opportunities and challenges related to shale oil and gas development. His input on the social effects of the gas boom is beneficial for that side of the project. 


\section{Cameron Spaur - Inspector for MarkWest Energy}

Mr. Spaur gives first hand account of what it's like to being on the ground, dealing with property owners and dealing with the dangers that are entailed in hydraulic fracturing operations. He depicts how important the employment aspect of the gas boom is, and presents the personal trials and feelings of the gas company employees themselves.

11. Richard Smith - Director of Sales at C\&J Energy Solutions

Richard Smith is a WVU graduate and works for C\&J Energy Solutions, a massive provider of hydraulic fracturing gas well construction, completion and extraction in the United States and Western Canada. Richard has worked different positions within the company, working in the Middle East several years ago, and is now a project manager for drilling operations in the Northeast American region, specifically on the Marcellus Shale.

Richard represents the population benefiting economically from the practice of hydraulic fracturing.

Questions for subjects: These questions were used as a base for all my subjects. They were, of course, tailored to each subject category, but this standardized list of questions related to the tension between economic prosperity and health effects were used, for better comparison of answers on the topic. Because these questions were being asked to elicit responses in story form for a podcast, they are framed conversationally. The initial questions are broad and meant to get subjects talking on a theme, but then the interviewer followed up with questions for specific examples and details.

1. Tell me about yourself a bit. Your family, your background, your relationship to West Virginia and how you came to live here.

2. How would you personally define a healthy community?

3. Depending on subject:

Tell me how you came to learn of hydraulic fracturing in your area?

How did you come to work for a hydraulic fracturing company? 
4. What did you think hydraulic fracturing was going to be like before you saw it up close, and how did the reality differ or fall in line with what you imagined?

5. How do you feel hydraulic fracturing has affected you health-wise, if at all? Are there any specific injuries or illnesses that you or your family members have suffered since hydraulic fracturing operations commenced in your environment?

5. What personal values guide your assessment of the benefits/harms of hydraulic fracturing operations?

6. What impact to do you feel hydraulic fracturing has had on the economy of your community as a whole? What are examples of it affecting you, financially?

7. How would you describe how representatives and legislators in West Virginia stand on hydraulic fracturing-related issues? Are you happy with their work?

8. How would you compare the hydraulic fracturing industry to the coal mining industry here in West Virginia?

9. Do you feel the potential economic benefits outweigh the potential adverse environmental- and health effects? Why?

10. What are your hopes for the future of your county and state, in terms of gas extraction development? Where do you see yourself in ten years

\section{Website}

The multimedia project was set up on a website, www.gascounty.com, accessible to everyone. The website hosting service Squarespace was used as it is relatively easy to set up, modify and tailor to the user's purpose. The site was split up in different sections, so users could easily navigate through the website for the material they want to access. The finished version had text information and background on hydraulic fracturing, the series of podcasts, an interactive timeline, a video piece, a photo gallery, and an "About" page. 


\section{Hydraulic Fracturing Overview}

One part of the website is an overview about hydraulic fracturing, its history, why it is considered controversial and the relationship between hydraulic fracturing and the state of West Virginia. Essentially, it is a shortened, more easily readable version of the literature review.

\section{Video Piece}

A video reporting piece about increased truck traffic in Doddridge County due to the hydraulic fracturing industry, was incorporated into the website. An important, but often overlooked, aspect of the industry, the heavy traffic affects the community in various ways, both positively and negatively. It is one of the only topics that residents agree on being a negative effect of the emergence of the hydraulic fracturing boom.

\section{Changes to Methodology from Original Proposal}

The methodology above is written retrospectively, listing the steps taken to complete the project. In the initial project proposal the methodology for completing the project was different than what was ultimately done. Changes and additions are, as follows:

The original methodology called for the inclusion of three to four individuals who opposed hydraulic fracturing in their community. Initially, there were three to four individuals meant to be interviewed on the supporting/industry side. In the end, there were two industry employees interviewed, but as the interviewing process commenced, there was a need for a more balanced discussion from the middle of the opinion spectrum, so it was decided to pursue three non-affiliated West Union residents instead. This was also to get a wider range on the topic (effect on education, law enforcement, and small businesses). The original plan anticipated two specialists on the subject. That went through, in addition to a DEP inspector.

Another difference between methodologies are the number of final podcasts. Initially, by creating eight to ten short podcasts, each interview subject was to be the focus of his/her interview, but as there was a substantial overlap of opinions and ideas, and the project had developed into a less binary research of just for and against, I wanted to include a more wider range of the gas boom's impact and show the tensions between various community values. I decided to produce four longer 
podcasts, organized around shared themes and have a more conversational tone, mixing fact-based reporting with personal stories and opinions.

\section{The Professional Project's Summary}

\section{The Project's Chronology}

The project started in the beginning of October 2016, when I began researching horizontal hydraulic fracturing and its impact on West Virginia. The reason why I chose the project was actually due to Professor Lois Raimondo suggesting the topic while I was asking around and looking for inspiration. I felt it was an important and current subject, and tied into my interest in environmental journalism. After researching the topic and seeing how it has changed the economic and environmental landscape of the state, I decided to narrow the subject. There had already been awardwinning documentaries made about hydraulic fracturing in the Appalachian region, and the topic had been covered on the national level through various mediums. But I found a niche; while several documentary projects had done case studies on hydraulic fracturing in Pennsylvania, Colorado and other regions, I didn't find any work that focused strictly on small communities in West Virginia. I chose Doddridge County in to do the comprehensive qualitative multimedia study on, due to the fact that it's one of the main natural gas extraction locations in West Virginia. There had been a focus group study conducted on several residents in the county regarding hydraulic fracturing two years prior, but no one had created a visual project about the area. I also had contacts there, as I had previously interviewed Lyndia Ervolina, one of my subjects, about truck traffic in the region.

I started contacting various residents, mainly the Ervolinas and Mirijana Beram to set up interviews later on. I made good use of Dr. Michael McCawley, who supplied me with contacts, data, and advice. Before I conducted the interviews, I wrote my literature review. This was the most difficult part of the project, as I was venturing into a scientific world that I had barely heard of before. The proposal submitted and defended to my committee members was rather elementary, and it was clear that the project needed a more defined and concise direction. After defining my objectives more clearly, I finally finished a passable draft of my proposal in mid- 
spring. Soon after, I interviewed Lindsey Ervolina and Mirijana Beram on separate occasions. They both took me out on the roads of Doddridge County and showed me the industrial activity in the area; an opportunity I used to get photographs and video bits for my project, in addition to interview footage and natural sound. For my interviews with Professor Joshua Fershee, Richard Smith, Dr. Michael McCawley, Dr. Paul Ziemkiewicz and Dr. Henry J. Harmon, I set up interviews through email correspondence, and they were later conducted in office settings. All of these interviews were recorded in the spring till late May 2017, except for Dr. Harmon's, which was recorded in December 2017.

For the three interviews inside West Union with Christina Trent, Sheriff Michael Headley, and Principal Kuhns, I hadn't prearranged any of them. I figured I would have better luck showing my face and asking them in person, since it's a rather delicate subject to some. This went well, although the sheriff wasn't available at first. I set up a time with his secretary the next day.

Although I knew that this "let's just see what happens" attitude in a research project may be considered unprofessional by some, I believe this is the essence of investigative journalism. I also counted on a snowball effect, meaning I'd get contacts through my interviews. That was true in the instance of Christina Trent, who introduced me to Cameron Spaur, the MarkWest Energy inspector I interviewed.

As a part of my research, I had countless back-and-forth email conversations with various governmental entities and gas company spokespeople and employees, such as the Bureau of Labor Statistics, West Virginia Department of Transportation, the Independent Oil \& Gas Association of West Virginia, and many more.

After conducting all my interviews, taking all my photographs, assembling the website together and editing my podcasts with Adobe Premiere, which included at least five drafts of each episode over a period of seven months, my material was mostly finished in early February 2018, 14 months later, pending final feedback and project defense in February/March 2018. 


\section{Discussion and Conclusions}

The purpose of this project was to show the implications of the emergence of the horizontal fracturing industry on individual residents and Doddridge County as a whole through personal interviews, while maintaining a standard of objectivity and fact-based reporting. The intended goal was for the study to be looked at as a microscopic view of an issue that is affecting many areas around the state and nation, where hydraulic fracturing is a big part of the economy. From a more personal standpoint, the project is a showcase of my ability to report through various mediums, be it text, audio, video, or other areas of journalism.

The research and completion of the project has taught me a lot. It has taught me to always report objectively; leaving no stone unturned, and for each claim, there is a counter argument. All sentimental claims must be qualified with factual information, and the Internet is a great tool for research, but must be used correctly.

My interviewing skills have improved drastically due to this interview-heavy project, and so have my editing skills. I have also gone from a novice to a decent audio producer; during my first interviews, I twice had to re-record parts of interviews because I forgot to press the record button.

In general, I've become a better researcher, more confident reporter, and hold myself to a higher standard in terms of factual reporting.

\section{Limitations and Suggested Future Research}

Overall, I'm pleased with the fact that I managed to follow through on my original idea of interviewing residents who are both for, and against the practice of hydraulic fracturing, in addition to getting great input from specialists on the topic. I feel like I've covered most areas of importance that play into the tension between different stakeholders in the county regarding this recent gas boom. Furthermore, I feel like I've managed to break down the fundamentals of hydraulic fracturing and its impact in a coherent manner, so the information is understood by most. That said, there were a few shortcomings and limitations during my research.

I would have liked to get one more interview subject from the opposition side, preferably a young resident. The same is true about supporters of hydraulic fracturing. Overall, younger generations weren't represented enough, if at all. 
I had difficulty accessing the health data and specific complaints of Doddridge County residents, but this would be very important to see quantitatively whether there's a correlation between doctor visits and the rise in fracking wells in the county through the years. Additionally, it would have been valuable to interview a local doctor familiar with some of the health claims. I made multiple attempts to contact health departments and clinics in the county, but to no avail. No doctor was willing to talk to me, unfortunately. I tried countering this with number of inpatients through the years in neighboring Pennsylvania, to give some comparable correlation between the number of wells and health deterioration.

I had a hard time finding data on whether gas employees where from West Virginia, or from out-of-state. This was mainly due to Bureau of Labor Statistics disclosure standards. The gas companies I contacted couldn't supply me with that exact information, and their sustainability reports' employment data didn't have what I was looking for. For this data, I had to resort to vague, objective comments by gas companies' spokespeople, found online.

When it comes to further research, I obviously recommend starting with the missing data above. Furthermore, I suggest monitoring how the ongoing mass litigation lawsuits in West Virginia conclude, and follow up on their implications for the future of drilling in the state.

Another rich area for exploration would be a deep dive into landowner surface rights vs. mineral rights and the legal disputes that have arisen in the area.

I'd also recommend looking further into the imminent exportation of natural gas to the transportation facilities on the East Coast, to see what this shift in business (with gas being used mainly for export overseas instead of consumption inside the country) will entail for the economy, whether it's the United States, West Virginia, or Doddridge County. 


\section{Bibliography}

Altheide, D. L. (1996). Qualitative media analysis. Thousand Oaks: Sage

Publications.

American Oil \& Gas Historical Society. (2016). Shooters - A "Fracking" History American Oil \& Gas Historical Society. Retrieved November 16, 2016, from http://aoghs.org/technology/hydraulic-fracturing/

American Petroleum Institute (2013). Economic Impacts of the Oil and Natural Gas Industry on the US Economy in 2011. Retrieved December 6 from http://www.api.org/ /media/Files/Policy/Jobs/Economic_impacts_Ong_2011. pdf

American Petroleum Institute (2013). Economic Impacts of the Oil and Natural Gas Industry on the US Economy in 2011. Retrieved December 6 from http://www.api.org/ /media/Files/Policy/Jobs/Economic_impacts_Ong_2011. pdf

Andrews, A., Folger, P., Humphries, M., Copeland, C., Tiesmann, M., Meltz, R., \& Brougher, C. (2009, October 30). Unconventional Gas Shales: Development, Technology, and Policy Issues. Congressional Research Service. Retrieved November 16, 2016, from http://www.fas.org/sgp/crs/misc/R40894.pdf

Associated Press (January 6, 2014). Water in at least three U.S. states is polluted from FRACKING as hundreds of complaints are reported across the country.

Retrieved December 6, 2016 from http://www.dailymail.co.uk/news/article2534508/Water-three-U-S-states-Pennsylvania-Ohio-West-Virginia-pollutedFRACKING.html

Bao, X. \& Eaton, D. (2016). Fault activation by hydraulic fracturing in western Canada. Science. http://dx.doi.org/10.1126/science.aag2583. Retrieved November 21, 2016 from http://science.sciencemag.org/content/early/2016/11/16/science.aag2583

Bowermaster, J. \& Ruffalo, M. (Producer), \& Bowermaster, J. (Director). (2016). Dear President Obama. [Motion Picture] United States: Ocean 8 Films.

Fox, J., Adlesic, T., Gandour, M. (Producer), \& Fox, J., Liptay, S. (Director). (2010). Gasland. [Motion Picture] United States.

BBC (December 16, 2015). What is fracking and why is it controversial? Retrieved November 21, 2016 from http://www.bbc.co.uk/news/uk-14432401

Beard, D. (2012, Apr 08). Drilling to W.va.'s future. McClatchy - Tribune Business News Retrieved November 19, 2016, from http://search.proquest.com/docview/979621386?accountid=2837 
BP Oil (June, 2016). BP Oil's Statistical Review of World Energy June 2016. Retrieved November 18, 2016, from http://www.fas.org/sgp/crs/misc/R40894.pdf

CBO (December, 2014). The Economic and Budgetary Effects of Producing Oil and Natural Gas From Shale. Congress of the United States Congressional Budget Office. Retrieved February 6, 2017 from https://www.cbo.gov/sites/default/files/113th-congress-20132014/reports/49815-effectsofshaleproduction.pdf

Charleston Gazette-Mail, Jan 14, 2015). Tomblin calls for study of increased deaths from gas-drilling boom. Retrieved Feb 6, 2018 from https://www.wvgazettemail.com/news/politics/tomblin-calls-for-study-ofincreased-deaths-from-gas-drilling/article 21d6342f-c5dd-54ee-bd91534ece13373a.html

CNN (September 3, 2016). Oklahoma orders shutdown of 37 wells after earthquake. CNN. Retrieved December 8, 2016 from http://money.cnn.com/2016/09/03/news/economy/oklahoma-earthquakefracking-oil/

CNN (February 6, 2011). 'Fracking' protesters say drilling jobs not worth environmental risks

Committee on Energy and Commerce. Retrieved February 7, 2017 from http://www.cnn.com/2011/US/09/20/philadelphia.fracking.protests/

CNN. (April, 2011). Chemicals Used in Hydraulic Fracking (Rep.). (n.d.). Retrieved November 17, 2016, from https://conservationco.org/admin/wpcontent/uploads/2013/02/Final-Rebuttal-Exhibits.pdf-Adobe-Acrobat-Pro.pdf.

Cohen, B., Goldsmith, S., Johnson L., \& O’Neill, A. (2016). "In the Air: Visualizing What We Breathe". Panel at the Reed College of Media Innovation Center at West Virginia University.

Columbia University (April, 2017). Can Coal Make a Comeback? Houser, T., Bordoff, J. \& Marsters, P. Retrieved May 172017 from http://energypolicy.columbia.edu/sites/default/files/energy/Center\%20on $\% 20$ Global\%20Energy\%20Policy\%20Can\%20Coal\%20Make\%20a\%20Comeback \%20April\%202017.pdf

DiGiulio, D. \& Jackson, R. (2016). Impact to Underground Sources of Drinking Water and Domestic Wells from Production Well Stimulation and Completion Practices in the Pavillion, Wyoming, Field. Environmental Science \& Technology. Retrieved 20 November 2016, from http://pubs.acs.org/doi/ipdf/10.1021/acs.est.5b04970 
Ellsworth, W. (2013). Injection-Induced Earthquakes. Science, 341(6142), 12259421225942. http://dx.doi.org/10.1126/science.1225942. Retrieved November 21, 2016 from $\mathrm{http}: / /$ science.sciencemag.org/content/341/6142/1225942.full

The Exponent Telegraph (Mar 29, 2017). MarkWest to invest over $\$ 200$ million in Sherwood Plant in Doddridge County. Retrieved Nov 10, 2017 from https://www.theet.com/progress/energy/markwest-to-invest-over-million-insherwood-plant-in-doddridge/article f5b986f1-1ebb-57ce-97a30b7deee2c38e.html

The Exponent Telegraph (Jul, 24, 2013). Gas well worker injured in July 5 Doddridge blast dies. Retrieved Feb 6, 2018 from https://www.wvnews.com/theet/news/local/gas-well-worker-injured-in-julydoddridge-blast-dies/article 8c312092-f4d4-11e2-94ba-001a4bcf887a.html

FactCheck (June 5, 2016). Clearing up Claims on EPA Fracking Study. The Annenberg Public Policy Center. Retrieved December 8, 2016 from http://www.factcheck.org/2015/06/clearing-up-claims-on-epa-fracking-study/

Facebook (2017) Frack Check $W V$. Facebook group. Retrieved Nov 17, 2017 from https://www.facebook.com/frackcheckwv/?ref=br_rs

Finkel, M., \& Hays, J. (2013). The implications of unconventional drilling for natural gas: A global public health concern. Public Health, 127(10), 889-893. doi:10.1016/j.puhe.2013.07.005. Retrieved November 15, 2016, from http://ac.els-cdn.com/S0033350613002412/1-s2.0-S0033350613002412main.pdf? tid=acc65564-b4ef-11e6-805a00000aab0f6b\&acdnat $=1480285397 \quad 90 \mathrm{a} 652 \mathrm{a} 1033 \mathrm{f} 4946 \mathrm{affe} 2 \mathrm{c} 4 \mathrm{~b} 8 \mathrm{cc} 7086 \mathrm{e}$

Fox, J., Adlesic, T., Gandour, M. (Producer), \& Fox, J., Liptay, S. (Director). (2010). Gasland. [Motion Picture] United States: HBO Documentary Films.

Fox, J., Adlesic, T., Gandour, M. (January 25, 2017). Gasland Website. Retrieved January 25, 2017 from http://one.gaslandthemovie.com/home

Frohlich, C. (2012). Induced or Triggered Earthquakes in Texas: Assessment of Current Knowledge and Suggestions for Future Research. University of Texas. Retrieved January 17, 2017 from http://earthquake.usgs.gov/research/external/reports/G12AP20001.pdf

Gandossi, L. (2013). An overview of hydraulic fracturing and other formation stimulation technologies for shale gas production (p. 7, Rep.). Luxembourg: Publications Office of the European Union. Retrieved November 14, 2016, from http://publications.jrc.ec.europa.eu/repository/bitstream/111111111/30129/1/a $\mathrm{n}$ overview of hydraulic fracturing and other stimulation technologies (2).pdf

Hausman, C. \& Kellogg R. (2015). Welfare and Distributional Implications of Shale Gas. Brookings Papers on Economic Activity. Retrieved December 8, 2015 
from https://www.brookings.edu/wp-

content/uploads/2015/03/2015a hausman.pdf

Harkness, J., Dwyer, G., Warner, N., Parker, K., Mitch, W., Vengosh, A. (2015). Iodide, Bromide, and Ammonium in Hydraulic Fracturing and Oil and Gas Wastewaters: Environmental Implications. Environmental Science \& Technology. Retrieved February 16, 2017 from http://pubs.acs.org/doi/pdf/10.1021/es504654n

Henley, P. (2013). From Documentation to Representation: Recovering the Films of Margaret Mead and Gregory Bateson. Visual Anthropology, 26(2), 75-108. doi:10.1080/08949468.2013.751857 Retrieved January 30, 2017 from http://web.b.ebscohost.com/ehost/pdfviewer/pdfviewer?sid=01f78160-73a64a99-836a-833483fcb7ed\%40sessionmgr120\&vid=9\&hid=124

The Intelligencer (Dec 12, 2016). More Money Coming to Northern Panhandle Counties from Gas and Oil. The Intelligencer. Wheeling News- Register. Retrieved Nov. 10, 2017 from http://www.theintelligencer.net/news/topheadlines/2016/12/more-money-coming-to-northern-panhandle-counties-fromgas-and-oil/

Jemielita T, Gerton GL, Neidell M, Chillrud S, Yan B, et al. (2015) Unconventional Gas and Oil Drilling Is Associated with Increased Hospital Utilization Rates. PLOS ONE 10(7): e0131093. Retrieved Nov 17 from http://journals.plos.org/plosone/article?id=10.1371/journal.pone. 0131093

Kelso, M. (December 2016). 1.7 Million Wells in the U.S. - A 2015 Update. FracTracker Alliance Retrieved December 7, 2016 from https://www.fractracker.org/2015/08/1-7-million-wells/

Kipen, H. M., Gandhi, S., Rich, D. Q., Ohman-Strickland, P., Laumbach, R., Fan, Z.H., ... Madura, K. (2011). Acute Decreases in Proteasome Pathway Activity after Inhalation of Fresh Diesel Exhaust or Secondary Organic Aerosol. Environmental Health Perspectives, 119(5), 658-663. http://doi.org/10.1289/ehp.1002784

King, G. E. (2012). Hydraulic Fracturing 101: What Every Representative, Environmentalist, Regulator, Reporter, Investor, University Researcher, Neighbor, and Engineer Should Know About Hydraulic Fracturing Risk. Journal of Petroleum Technology, 64(04), 34-42. doi:10.2118/04120034-jpt. Retrieved November 15, 2016 from http://www.kgs.ku.edu/PRS/Fracturing/Frac_Paper_SPE_152596.pdf

Lwebuga-Mukasa, J., Oyana, T. \& Johnson, C. (2005). Local Ecological Factors, Ultrafine Particulate Concentrations, and Asthma Prevalence Rates in Buffalo, New York, Neighborhoods. Journal of Asthma, Volume 42, 2005 - Issue 5. Retrieved Nov 15, 2017 from http://www.tandfonline.com/doi/full/10.1081/JAS62972? scroll=top\&needAccess $=$ true 
Mader, D. (1989). Hydraulic proppant fracturing and gravel packing (1st ed.). Amsterdam: Elsevier.

Marcellus Drilling News (Aug 22, 2016). Update on Antero's \$275M Wastewater Facility in WV. Retrieved Nov 10, 2017 from http://marcellusdrilling.com/2016/08/update-on-anteros-275m-wastewaterfacility-in-wv/

McAleer, P., McElhinney, A., Alberstat, P., Sidles, B., Essex, B. \& Aliman, D. (Producer) \& McAleer, P., McElhinney, A. \& Segieda, M. (Director) (2013). Fracknation. [Motion Picture] United States: Ann and Phelim Media.

Mckenzie, L., Guo, R., Witter, R., Savitz, D., Newman, L., \& Adgate, J. (2015). Birth Outcomes and Maternal Residential Proximity to Natural Gas Development in Rural Colorado. Everyday Environmental Toxins, 111-130. doi:10.1201/b18221-11

Mauro, F., Wood, M., Michele, M., Price, M., Herzenberg, S. \& Ward, S. (November 2013). Multi Shale Research. 'Exaggerating the Employment Impacts of Shale Drilling: How and Why. Retrieved December 6 from https://pennbpc.org/sites/pennbpc.org/files/MSSRC-Employment-Impact-1121-2013.pdf

Merriam-Webster (2017). 'Podcast', Retrieved February 16, 2017 from https://www.merriam-webster.com/dictionary/podcast

Mills, N.L., Tornquvist, H., Gonzalez., M.C., Vink, E., Robinson, S.D., Soderberg, S., Boon, N.A., Donaldson, K., Sandstrom, T., Blomberg, A., Newby, D.E., 2007. Ischemic and Thrombotic Effects of Dilute Diesel-Exhaust Inhalation in Men with Coronary Heart Disease. N. Engl. J. Med. 357, 1075-1082. Retrieved Nov 15, 2017 from http://www.nejm.org/doi/full/10.1056/NEJMoa066314\#t=article

Mineral Wise (2016). Marcellus Shale Location. Retrieved December 6, 2016 from http://www.mineralweb.com/directory/shale-plays/marcellus-shale-westvirginia/

The National Institute of Occupational Safety and Health (2008). NIOSH Announces Schedule for Free, Confidential Screening in West Virginia for Coal Workers' Pneumoconiosis. Retrieved Nov 22, 2017 from https://www.cdc.gov/niosh/updates/upd-02-15-08.html

News 21 (2011). Powering a Nation - Coal: A Love Story. Carnegie-Knight Initiative on the Future of Journalism Education. Retrieved January 25, 2017 from http://www.poweringanation.org/coal/

Nichols, B. (2010). Introduction to Documentary, Second Edition. Bloomington: Indiana University Press. 
OK Energy Today (January 30, 2017). Little Movement Seen in Sierra Club Earthquake Lawsuit Against 4 Oklahoma Energy Companies. Retrieved March 28, 2017 from http://okenergytoday.com/2017/01/little-movementseen-sierra-club-earthquake-lawsuit-4-oklahoma-energy-companies/

Omara, M., Sullivan, M. R., Xiang, L., Subramanian, R., Robinson, A. L., \& Presto, A. A. (2016). Methane Emissions from Conventional and Unconventional Natural Gas Production Sites in the Marcellus Shale Basin. Environmental Science \& Technology, 50(4), 2099-2107. doi:10.1021/acs.est.5b05503

Paulik, L., Donald, C., Smith, B., Tidwell, L., Hobbie, K., \& Kincl, L. et al. (2016). Emissions of Polycyclic Aromatic Hydrocarbons from Natural Gas Extraction into Air. Environmental Science \& Technology, 50(14), 7921-7929. http://dx.doi.org/10.1021/acs.est.6b02762. Retrieved November 21, 2016, from http://pubs.acs.org/doi/pdf/10.1021/acs.est.6b02762

Petersen, M., Mueller, C.S., Moschetti, S.M., Lienos, A.L., Ellsworth, W.L., Michael, J.A., Rubinstein, J.L., McGarr, A.F. \& Rukstales, K.S. (2016). 2016 one-year seismic hazard forecast for the Central and Eastern United States from induced and natural earthquakes. The United States Geological Survey. Retrieved December 8, 2016 from https://pubs.usgs.gov/of/2016/1035/ofr20161035ver1_1.pdf

Physicians for Social Responsibility. (2014). Hydraulic Fracturing and Your Health: Air Contamination. Retrieved November 21, 2016 from http://www.psr.org/assets/pdfs/fracking-and-air-pollution.pdf

Planet Money (August 17, 2016). Oil \#3: How Fracking Changed the World. NPR. Retrieved January 25, 2017 from http://www.npr.org/sections/money/2016/08/17/490375230/oil-3-howfracking-changed-the-world

Public Herald (September 21, 2016) 9 Ways Pennsylvania DEP Water Contamination Cases Related to Fracking are 'Cooked'. Retrieved November 20, 2016 from https://www.dropbox.com/s/mbdxaix9s4acnol/DEP COMPLAINT INVESTI GATION_Report_summary_update.pdf?dl=0

Rasmussen, S. G., Ogburn, E. L., McCormack, M., Casey, J. A., Bandeen-Roche, K., Mercer, D. G., \& Schwartz, B. S. (2016). Association between unconventional natural gas development in the marcellus shale and asthma exacerbations. JAMA Internal Medicine, 176(9), 1334-1343. doi:http://dx.doi.org/10.1001/jamainternmed.2016.2436

Robbins, K. (2016). Awakening the Slumbering Giant: How Horizontal Drilling Technology Brought the Endangered Species Act to Bear on Hydraulic Fracturing. Case Western Reserve Law Review, 63(4). Retrieved Novemebr 18,2016 , from 
https://web.archive.org/web/20140326094824/http://law.case.edu/journals/La wReview/Documents/63CaseWResLRev4.6.Article.pdf

Rosenberg, A. A., Phartiyal, P., Goldman, G., \& Branscomb, L. M. (2014). Exposing fracking to sunlight. Issues in Science and Technology, 31(1), 74-79. Retrieved November 18, 2016, from http://search.proquest.com/docview/1649801219?accountid $=2837$

Rothstein, A. (1974). Photojournalism. Garden City, N.Y: Amphoto.

Rumpler, J.\& Ridlington, E. Fracking By The Numbers: Key Impacts Of Dirty Drilling At The State And National Level. America Research \& Policy Center, 2016. Web. 16 Nov. 2016. Retrieved November 16, 2016 from http://www.environmentamerica.org/sites/environment/files/reports/EA Frack ingNumbers_scrn.pdf

Ryan, J. (2016). PENNSYLVANIA'S ECONOMY. Let's Take A Look At Pennsylvania. Retrieved February 1, 2016 from http://web.b.ebscohost.com/ehost/detail/detail?vid=4\&sid=f54aef19-50924d81-b27b831a938f079e\%40sessionmgr101\&hid $=118 \&$ bdata $=$ JnNpdGU9ZWhvc3QtbG $12 \mathrm{ZQ} \% 3 \mathrm{~d} \% 3 \mathrm{~d} \# \mathrm{db}=\mathrm{f} 5 \mathrm{~h} \& \mathrm{AN}=14151153$

Sangaramoorthy, T., Jamison, A. M., Boyle, M. D., Payne-Sturges, D., Sapkota, A., Milton, D. K., \& Wilson, S. M. (2016). Place-based perceptions of the impacts of fracking along the marcellus shale. Social Science \& Medicine, 151, 27. Retrieved November 20, 2016, from http://ac.elscdn.com/S0277953616300028/1-s2.0-S0277953616300028main.pdf? tid=6b2334ae-b51e-11e6-bde500000aacb35d\&acdnat $=1480305473 \_68 \mathrm{~b} 5 \mathrm{cc} 2 \mathrm{e} 06 \mathrm{af} 64 \mathrm{a} 1 \mathrm{~b} 23588 \mathrm{~d} 2 \mathrm{~d} 7729 \mathrm{c} 06$

Sierra Club (February 16, 2016), Environmental Groups File Fracking Lawsuit Against Three Energy Companies Operating in Oklahoma. Retrieved November 21, 2016 from http://content.sierraclub.org/pressreleases/2016/02/environmental-groups-file-fracking-lawsuit-against-threeenergy-companies.

Srebotnjak, T. \& Rotkin-Ellman, M. (December 2014). Hydraulic Fracturing Threatens Public Health and Communities. Natural Resource Defense Council. Retrieved November 20, 2016, from https://www.nrdc.org/sites/default/files/fracking-air-pollution-IB.pdf

Srebotnjak, T., Rotkin-Ellman, M. (December, 2014). Fracking Fumes: Air Pollution from

Stanford Environmental Law Journal (2014). Local Government Fracking Regulations: A Colorado Case Study. Stanford University. Retrieved December 8, 2016 from https://journals.law.stanford.edu/sites/default/files/stanford-environmentallaw-journal-selj/print $/ 2014 / 01 / \mathrm{h}$ _minor_article_-_web_0.pdf 
Times-Call (August 8, 2016), Weld County resident says fracking is costing him sleep. Retrieved November 21, 2016 from http://www.timescall.com/longmont-local-news/ci_26350144/weld-countyresident-says-fracking-is-costing-him SEE ENTRY ABOVE FOR "HYDRAULIC FRACTURING THREATENS PUBLIC HEALTH AND COMMUNITIES . . .

Time-Life Books. (1983). Photojournalism. Alexandria, Va: Time-Life Books.

Tribune Business News (December 7, 2012). UT Accepts Panel Criticism of Fracking Report, Agrees to Change Policies. Retrieved January 16, 2017 from http://search.proquest.com/docview/1223463554/5CD3A3735B5241EFPQ/4? accountid $=2837$

U.S. Census Bureau (2017). Quickfacts: Doddridge County, West Virginia. Retrieved May 5, 2017 from https://www.census.gov/quickfacts/table/POP060210/54017

U.S. EIA (2016a). Assessment of the Potential Impacts of Hydraulic Fracturing for Oil and Gas on Drinking Water Resources. United States Environmental Protection Agency. Retrieved from https://www.epa.gov/sites/production/files/201506/documents/hf_es_erd_jun2015.pdf.

U.S. EIA (2015) Annual Coal Report 2015. Retrieved November 30, 2016 from http://www.eia.gov/coal/annual/pdf/acr.pdf

U.S. EPA (2015b). Hydraulic Fracturing for Oil and Gas: Impacts from the Hydraulic Fracturing Water Cycle on Drinking Water Resources in the United States (Final Report). U.S. Environmental Protection Agency, Washington, DC, EPA/600/R-16/236F, 2015. Retrieved January 3, 2017 from https://cfpub.epa.gov/ncea/hfstudy/recordisplay.cfm?deid=332990

U.S. EIA (2016b). West Virginia: Profile Overview. Retrieved December 6, 2016 from http://www.eia.gov/state/print.cfm?sid=WV

U.S. EIA (June, 2012). Annual Energy Outlook 2012 with Projections to 2035. U.S. Energy Information Administration. Retrieved November 18, 2016, from http://www.eia.gov/forecasts/aeo/pdf/0383(2012).pdf

United States Census Buerau. 2016. West Virginia Median Household Income. Retrieved December 7, 2016 from http://www.census.gov/searchresults.html? $\mathrm{q}=$ median + income + by + state + west + virginia\&page $=1 \&$ stateGeo $=$ none\&searchtype $=$ web

U. S. EPA (2016c). Natural Gas STAR Methane Challenge Program. U.S. Energy Information Administration. Retrieved December 8, 2016 from https://www.epa.gov/natural-gas-star-program/natural-gas-star-methanechallenge-program 
U. S. EPA (2016d). Annual Energy Outlook 2017. U.S. Energy Information Administration. Retrieved Februar 4, 2017 from http://www.eia.gov/outlooks/aeo/pdf/0383(2017).pdf

West Virginia University (2016). Retrieved November 21, 2016 from http://wvutoday.wvu.edu/n/2016/07/20/research-at-wvu-concludes-wastefrom-test-fracking-wells-safe-to-be-on-highways

What is fracking and why is it so controversial? (2016, May 24). The Week. Retrieved November 15, 2016, from http://www.theweek.co.uk/fracking/62121/what-isfracking-and-why-is-it-so-controversial

What is Fracking? (2016). Retrieved November 14, 2016, from http://www.what-isfracking.com/

Wimmer, R. D., \& Dominick, J. R. (1991). Mass media research: An introduction. Belmont, Calif: Wadsworth Pub. Co.

WorkForce WV (2017). Employment and Wages 1995 - 2017. WorkForce West Virginia. Retrieved Nov 11, 2017 from http://lmi.workforcewv.org/Employment_N_Wages/EnW.html

WSAZ3 (May 13, 2017) Reported shots fired during protest in Fayette County. WSAZ 3 News Channel. Retrieved Nov 17, 2017 from http://www.wsaz.com/content/news/422180424.html

WV Center on Budget \& Policy (April, 2014). Impacts of Gas Drilling in Wetzel County. West Virginia Center on Budget \& Policy. Retrieved Nov 15, 2017 from http://www.wvpolicy.org/wp-content/uploads/2014/04/Impacts-ofDrilling-in-Wetzel-County.pdf

WV Center on Budget \& Policy (April, 2014). Impacts of Gas Drilling in Wetzel County. West Virginia Center on Budget \& Policy. Retrieved Nov 15, 2017 from http://www.wvpolicy.org/wp-content/uploads/2014/04/Impacts-ofDrilling-in-Wetzel-County.pdf

WV Division of Culture and History (2015). Story About One of the State's Most Interesting Characters. Retrieved May 16, 2017 from http://www.wvculture.org/history/notewv/dissdebr1.html

WV DEP (2017). Email from Henry J. Harmon, Deputy Chief of the Office of Oil and Gas: List of complaints from 2005-2017. Received Nov 22, 2017.

WV DEP (2017). Oil and Gas Production Data. West Virginia Department of Environmental Protection. Retrieved Nov 15, 2017 from http://dep.wv.gov/oiland-gas/databaseinfo/Pages/default.aspx 
WVU DEP (2015). 2015 Production Data. West Virginia Department of Environmental Protection. Retrieved May 17, from http://www.dep.wv.gov/oil-and-gas/databaseinfo/Pages/default.aspx

WV DEP (2017). WVDEP Oil and Gas - Well Search. West Virginia Department of Environmental Protection. Retrieved May 17, 2017 from https://apps.dep.wv.gov/oog/wellsearch/wellsearch.cfm?CFID $=3279363 \& \mathrm{CF}$ TOKEN $=74154247 \&$ jsessionid $=34306 \mathrm{ab} 04 \mathrm{ee} 339 \mathrm{e} 618497645306 \mathrm{f} 7 \mathrm{~d} 75181 \mathrm{dT}$ $\underline{\mathrm{R}}$

WV DEP (2018). Email communication with Jason Harmon, Deputy Chief of the Office of Oil \& Gas. Jan 30, 2018. Retrieved Feb 7, 2018.

WV DOT (2017). West Virginia DOT Traffic Counts. West Virginia Department of Transportation. Retrieved Nov 15, 2017 from http://geocounts.com/traffic/project/1471556443665? $1 \mathrm{lz}=38.48154475346391$, $\underline{-81.03790283203126,8}$

WV State Treasurer (2017). Oil and Gas Severance. Retrieved Nov. 10, 2017 from http://www.wvtreasury.com/Banking-Services/Revenue-Distributions/Oil-andGas-Severance

Vasi, I. B., Walker, E. T., Johnson, J. S. \& Tan, H. F. (2015). "No Fracking Way!” Documentary Film, Discursive Opportunity, and Local Opposition against Hydraulic Fracturing in the United States, 2010 to 2013. American Sociological Review. Retrieved January 25, 2017 from http://journals.sagepub.com/doi/pdf/10.1177/0003122415598534 